\title{
IAMJ
}

INTERNATIONAL

AYURVEDIC

MEDICAL JOURNAL

Review Article

ISSN: 2320-5091

Impact Factor: 6.719

\section{EFFICACY OF SOME INDIGENOUS HERBS ON YUVANAPIDIKA W.S.R. TO ACNE VULGARIS: A REVIEW}

\section{$\underline{\text { Lekshmy M}}{ }^{1}, \underline{\text { Shuchi Mitra }}^{2}$, $\underline{\text { adevendra Yadav }}^{3}, \underline{\text { Khem Chand Sharma }}^{4}$}

${ }^{1}$ P.G. Scholar, ${ }^{2}$ Associate Professor, ${ }^{3}$ Assistant Professor, ${ }^{4}$ Professor\& H.O.D

P.G. Department of Rasashastra and Bhaishajya Kalpana, Rishikul Campus, UAU, Dehradoon, Uttarakhand, India

Corresponding Author: lekshmymohandas723@gmail.com

https://doi.org/10.46607/iamj2509042021

(Published Online: April 2021)

Open Access

(C) International Ayurvedic Medical Journal, India 2021

Article Received: 28/03/2021 - Peer Reviewed: 30/03/2021 - Accepted for Publication: 31/03/2021

Check for updates

\begin{abstract}
Acne vulgaris is a chronic inflammatory disease mainly affecting the teenagers. As it is chronic and affects face mainly, it always causes negative psychological impact on human life. In a study conducted in 2015 acne affected 650 million people globally making it the most common skin disease worldwide. In a study of "Global burden of disease" it is revealed that acne was the $8^{\text {th }}$ common prevalent disease worldwide. In Ayurveda the features of Mukhadusika or Yuvanapidika can be correlated with Acne vulgaris. In modern medicine anti-biotics are mainly used for the treatment of acne. Due to increasing resistance of anti-microbial agents, side effects, and sometimes high cost of treatment, it is necessary to find herbal remedy for the cure of acne. In this article a review of efficacy of 5 potential herbal drugs for acne is done. These herbal drugs are Manjishta, Shalmali, Ghrit kumari, Daruharidra, and Yashtimadhu.
\end{abstract}

Keywords: Yuvanapidika, Mukhadushika, Manjistha, Shalmali, Daruharidra, Ghritakumari, Yasthimadhu

\section{INTRODUCTION}

Acne vulgaris is a long-term skin disease that occurs when dead skin cells and oil from skin clogs the hair follicle. It is a chronic inflammatory disease affecting pilo sebaceous unit (comprising hair follicle, hair shaft, sebaceous gland) and is one among the common dermatological condition worldwide. It is characterized by 
formation of open and closed comedones, papules, pustules, nodules and cyst. The primary factors involved in the development of acne involves androgen mediated stimulation of sebaceous gland activity, follicular hyper keratinization, bacterial growth and inflammation. The major skin bacteria that causes the formation of acne are Propionibacterium acne (P.acne) and Staphylococcus epidermidis ${ }^{1}$. P.acne is aerotolerant, anaeorobic, slow growing, gram-positive bacterium (rod shape) associated with acne ${ }^{2}$. In many cases acne causes permanent scarring and post inflammatory hyper pigmentation. It causes negative psychological impact on human life. So early and aggressive therapy for curing acne is very much needed ${ }^{3}$. In modern medicine topical agents like benzoyl peroxide, anti-biotics, retinoids etc are being used and in systemic therapy oral anti-biotics, hormonal therapy, isotretinoin and lesion removal treatment is done. Depending on the condition of disease, Phototherapy is also being used as a treatment for $\mathrm{acne}^{4}$. Also, the treatment includes antimicrobial hormones, corticosteroids, ultraviolet irradiation, and intra lesion steroid injection etc. These treatments are very expensive and have a lot of side effects ${ }^{5}$. Mukhadushika or Yuvanapidak mentioned by Ayurvedic Acharyas have similar symptoms to that of Acne vulgaris. Acharya Sushruta described Mukhadushika as Kshudraroga in Nidana sthana. According to Acharya Sushruta Mukhadushika are the eruptions that look like shalmalikantak localised on the face, caused during adult stage and caused by Vata, Kapha and Rakta dosha. ${ }^{6}$ Ayurvedic treatment for Mukha dooshika includes Shodhan and Shaman chikitsa. Shodhana chikitsa includes Vamana, Nasya and Siravyadha $a^{7,8,9,10,11}$. Shaman Chikitsa includes various Lepa $^{12}$. In this review 5 potential Anti -acne herbal drugs will be discussed for their efficacy as an application in the treatment of acne. They are Manjishta, Shalmali, Daruharidra, Ghrit Kumari and Yashtimadhu.

\section{Drug Review}

In Yogaratnakara, application of Shalmali kantak with milk and Manjishta with honey is explained in the treatment of Yuvana pidika ${ }^{13}$. Ashtanga Hridaya explains the use of Manjishta with honey in Vyanga ${ }^{14}$. As per
Charaka Samhita, the herbal drug Manjistha is included in Varnya (improving complexion) Mahakashaya $^{15}$. Bhaishajya Ratnavali explains the use of Shalmali kantak lepa for Mukha kanti ${ }^{16}$. Daruharidra is one of the ingredients in Saptachhadadi taila and Dwiharidradi taila mentioned by Bhaishajya Ratnavali in Kshudraroga chikitsa ${ }^{17,18}$. Both these Taila are useful for Yuvanapidika. Yashtimadhu is included in Varnya Mahakashaya of Charaka samhita and also in Sarivadi and Nyagrodhadi gana of Ashtanga Hridaya, Ashtanga Samgraha and Susrutha ${ }^{19,20,21,22,23,24}$. Herbs included in Sarivadi gana are used for Pitta-Rakta Vikara. Nyagrodhadi gana is varnya (Improves complexion). The alcoholic extract of thorns and bark of Shalmali possess very good anti-acne potential against Propionibacterium acne ${ }^{25}$. The phytoconstituents present in Shalmali such as saponins, tannins, phenolic compounds and glycosides are responsible for inhibition of bacterial growth and to be protective to plants against bacterial and fungal infections ${ }^{26}$ Manjistha has anti-acne effect through anti-bacterial, anti-inflammatory, antioxidant and anti-androgenic action. As acne is caused mainly due to these four causes, Manjistha is one of the most important drugs against acne. It is a good source of anthraquinone which is responsible for antioxidant, anti-inflammatory, anti-cancer, immunomodulation effects of this herbal drug. Manjistha is a well-known herbal drug used in blood and skin diseases $^{27}$. Amino acid is one of the ingredients present in Manjistha having the role of detoxification of blood. Another constituent present in Manjistha is saponin which is best cleansing agent. Phenolic compound present in Manjistha is having good antiseptic action. Hence it can be used in infection also. This phenolic compound also has antioxidant property which helps to prevent acne ${ }^{28}$. Alkaloid present in Daruharidra is responsible in inhibiting the action of $P$. acne and $S$. aureus $^{29}$. Berberis aristata showed the presence of alkaloids, flavonoids, phenol, sterol, terpenes, saponins and tannin in the phytochemical analysis of its ethanolic extract. Its extract showed significant result against $P$. acne, $M$. furfur (yeast) and S. epidermidis. Anti-acne effect of this herb is not only based on its anti-microbial 
activity but also on its antioxidant and anti-inflammatory properties by which they inhibit neutrophil migration and generation of reactive oxygen species $^{30}$. Glycyrrhiza glabra Linn contains important phytoconstituents such as Glycyrrhizin, glycyrrhizinic acid, glabrin $\mathrm{A}$ and $\mathrm{B}$ and isoflavones. It is used as anti-inflammatory, anti-bacterial, anti-fungal, anti-viral, anti-ulcer, anti-oxidant and skin whitening agent. The constituents such as saponin, alkaloids, flavonoids are responsible for its anti-bacterial property. The extract of liquorice is an effective pigment lightening agent. It is the safest pigment lightening agent with least side effects. Liquiritin present in liquorice extract disperses melanin. By this mechanism it induces skin lightening. Due to tyrosine inhibition activity it can be used to formulate cosmetic formulations with depigmenting activity $^{31}$. In one study it was proved that application of
Glycyrrhiza glabra with either water or honey improves complexion. It is very cost effective and safe $^{32}$. Aloe vera is a natural product frequently used in the field of Cosmetology. Many Cosmetic preparations are made from the mucilaginous tissue in the centre of aloe vera leaf which is called Aloe vera gel (AVG). Pharmacological action of AVG includes anti-inflammatory, anti-irritant, wound healing and anti-bacterial effects ${ }^{33}$. Aloe vera contains polysaccharides, lignin, enzymes, vitamins, minerals, amino acids, and salicylic acid and substances that can inhibit premature aging such as vitamin B2, B6, C, E and minerals such as manganese, selenium, nonessential aminoacids proline that can make the skin smoother, constantly hydrated, more elastic and protect it from free radical and degenerative effects $^{34}$

Table 1: Rasapanchaka of Drugs ${ }^{35}$

\begin{tabular}{|c|c|c|c|c|c|}
\hline Drug & Rasa & Guna & Virya & Vipaka & Karma \\
\hline $\begin{array}{l}\text { Shalmali } \\
\text { (Rubia cordifolia L.) }\end{array}$ & Madhura, Kashaya & Laghu, Snigdha, Pichila & Sita & Madhura & $\begin{array}{l}\text { Dahaprasamana } \\
\text { Raktapittahara } \\
\text { Rasayani } \\
\text { Shodhahara }\end{array}$ \\
\hline $\begin{array}{l}\text { Manjistha } \\
\text { (Salmalia malabarica) }\end{array}$ & Kashaya, Tikta, Madhura & Guru & Ushna & Katu & $\begin{array}{l}\text { Kaphapittashamaka } \\
\text { Varnya } \\
\text { Vishashodhaghna, } \\
\text { Krimighna } \\
\text { Sonithasthapana } \\
\text { Rasayana }\end{array}$ \\
\hline $\begin{array}{l}\text { Daruharidra } \\
\text { (Berberis aristata) }\end{array}$ & Tikta & Ruksa & Ushna & Katu & Doshapachana \\
\hline $\begin{array}{l}\text { Yashtimadhu } \\
\text { (Glycyrrhiza glabra L.) }\end{array}$ & Madhura & Guru, Snigdha & Sita & Madhura & $\begin{array}{l}\text { Pittashamak } \\
\text { Shodhahar } \\
\text { Varnya, } \\
\text { Kandughna } \\
\text { Kushtaghna }\end{array}$ \\
\hline $\begin{array}{l}\text { Kumari } \\
\text { (Aloe barbadensis) }\end{array}$ & Tikta & Guru, Snigdha, Pichila & Sita & Katu & $\begin{array}{l}\text { Shodhahara } \\
\text { Vranaropana } \\
\text { Raktashodhak } \\
\text { Twakdoshahara }\end{array}$ \\
\hline
\end{tabular}

\section{DISCUSSION}

Acne vulgaris is a common skin disorder which affects almost all individuals mainly during adolescent stage. Even though it is not a life-threatening disease it can produce cutaneous and emotional scar that may last for a lifetime. It causes anxiety, depression, and suicidal ideation in many individuals ${ }^{36}$. Lack of standardized treatment is a major drawback in the management of 
acne. Overuse of antibiotics as a treatment for acne causes antibiotic resistance. Primary factors involved in the formation of acne are androgen mediated hyper production of sebum, sloughing of Keratinocytes, Bacterial growth and Inflammation. Hence the herbal drugs having the properties of anti-androgenic, anti-bacterial, anti-inflammatory and antioxidant properties are beneficial in treating acne. Application of drugs having these properties definitely cause the alleviation of acne. Ayurvedic Acharyas mentioned Manjistha, Shalmali and Daruharidra in the treatment of acne. There is no reference of Ghrit Kumari and Yashtimadhu in classical texts for the management of acne. As Yashtimadhu is having Guru Guna and Sita Virya, it increases moisture which helps to prevent wrinkles. Without stripping the natural oil from the skin, it scrapes the excess oil secretion $^{37}$. Yashtimadhu has antioxidant, anti-inflammatory, anti-bacterial, skin lightening and skin tightening properties ${ }^{38}$. Aloe vera also have anti-inflammatory, antiseptic, antioxidant, antibacterial properties. Its extract showed greater antibacterial activity against Gram-positive bacteria as compared to Gram-negative bacteria ${ }^{39}$. The main bacteria causing acne i.e. P. acne is a Gram-positive bacterium. The absorption of Aloe vera through skin is four times faster than the absorption of water, it also helps to open the skin pores and hence helps in receiving the moisture and nutrients of the plant ${ }^{40}$. When we consider all these points it is very clear that these two drugs i.e. Ghrit Kumari and Yashtimadhu are also beneficial for acne.

\section{CONCLUSION}

It is hoped that this review of these herbal drugs would lead to establishing the efficacy of these herbs (Manjistha, Shalmali, Daruharidra, Ghrit Kumari and Yasthimadhu) as an application for treatment of acne. Inventing herbal remedies with least side effects is a very good alternative for patients suffering from the problems of acne.

\section{REFERENCES}

1. Elin Julianti, Anti-bacterial activity of Ethanolic extract of Cinnamon bark, honey, and their combination against Acne causing bacteria, Sci.pharm2017,85, 19
2. Shyam Baboo Prasad, In vitro Anti Acne activity of ethanolic extract of stem of Berberis aristata, International journal of Pharmacocgnosy and Phytochemical Research, 2017; 9(2), ISSN:0975-4873

3. Sara Moradi Tuchayi, Acne vulgaris, Article in Nature Reviews Disease Primers, 2015, Macmillan Publishers Ltd

4. Sanjay K Rathi, Acne vulgaris treatment: the current scenario, Indian Journal of dermatology, 2011;56(1)

5. Priyanka Yadav, "A clinical evaluation of the Jatiphaladi lepa and Lodhradi lepa in the management of Mukhadooshika w.s.r. to Acne vulgaris, Rajiv Gandhi University of Health Science, Bangalore, 2010

6. Sushrut samhita, Hindi Commentary on Nibandha samgraha by Dalhanacharya, Nidana sthana, Dr. Keval Krishna Takaral, 13/39, Page No:856, First edition 2014, Reprint 2016

7. Vd. Anantram Sharma, Susruta Samhuta Chikitsa, Varanasi: Chaukhambha Surbharti prakashan; 2010 .20/3637, Page no:332.

8. Dr. Brahmanand Tripathi, Ashtanga Hridayam, Uttara Sthana, Chaukhambha Sanskrit Prasthan. 2009 Shlok;32/3

9. Bhav prakasha by Bhishakratna Pandit \& ShriBrahma Shankar Mishra, Madhyama Khanda, Varanasi, Chaukhambha Sanskrit Sansthana, 2003, Shlok: 61/35, Page:587

10. Yoga Ratnakara, Vaidyalaxmipati Shastri edited by Bhishakratna Brahmashankar Shastri, Kshudrarogadhikara, Shlok no:1 Chaukhambha Prakashan, Varanasi. 2012

11. Bhaishajya Ratnavali, by Kaviraja Ambikadatta Shastri Kshudraroga Chikitsa, 60/37-38, Chaukhambha Sanskrit Sansthan, 2001

12. Sharngadhara Samhita, by Dr. Brahmanand Tripathi, Uttarakhanda-11/11. Chaukhambha Surbharti Prakashan, 2008

13. Yoga Ratnakara, Kshudraroga Chikitsa, Vidyotini Hindi Commentary, Sri Laxmipatishastri, Choukambha prakashan, Varanasi, Pageno:282

14. Ashtanga Hridaya, Vagbata with commentary of Sarvanga sundara of Arunadatta and Ayurveda Rasayana of Hemadri, Uttara sthana 32/16, Chaukhambha Orientalia, Reprint $10^{\text {th }}$ edition:2019, Page no:891.

15. Agnivesh, Charaka Samhita by Pt. Kashinath sastri, Sutra sthana 4/10, Chaukhambha Sanskrit Sansthan, Eightth edition, page no:61

16. Govind das sen, Bhaishajya Ratnavali, Chandraprabhakhya Hindi commentary by Sri. Jayadeva Vidyalankara, Sri Haridatta shastri, Page-628

17. Govind das sen, Bhaishajya Ratnavali, Vidyotini Hindi Commentary by Ambikadatta Shastri,60/155,156,157, Page no:670

18. Govind das sen, Bhaishajya Ratnavali, Vidyotini Hindi Commentary by Ambikadatta Shastri,60/107,108, 109, Page no:667. 
19. Agnivesh, Charaka Samhita by Pt. Kashinath sastri, Sutra sthana 4/10, Chaukhambha Sanskrit Sansthan, Eighth edition, page no:61

20. Gupta Atridev Kaviraj, Ashtanga samgraha, Sutra sthana16/5, Chaukhambha Krishnadas Academy, P.136

21. Gupta Atridev Kaviraj, Ashtanga samgraha, Sutra sthana16/35,36, Chaukhambha Krishnadas Academy, P.139

22. Gupta Atridev Kaviraj, Ashtanga hridaya, Sutra sthana 15/42, Chaukhambha prakashan, 2015, P.144

23. Dr. Keval Krishna Takaral, Susrut Samhita, Sutra sthana 38/40, Chaukhambha Orientalia, P.422

24. Dr. Keval Krishna Takaral, Susrut Samhita, Sutra sthana 38/48,49, Chaukhambha orientalia P.423

25. Vandana meena, Shalmali (Bombax ceiba): Versatality in its therapeutics, International Journal of Green Pharmacy, 2017,11(3)

26. K Girija, Evaluation of antimicrobial activity of various bark extract of Bombax malabaricum, Int. J. Pharm. Sci.Vol1(2), 2010, ISSN:0975-7538

27. Vandana meena, Manjistha (Rubia cordifolia)- A helping herb in cure of acne, Journal of Ayurveda and holistic medicine, vol-3(2), ISSN:2321-1563

28. Radha Gupta and Basant Gupta, Phytochemical analysis of Manjishtha (Rubia cordifolia Linn.) and its therapeutic relevance, The Pharma Innovation Journal 2017;6(7) 164-169

29. G. S. Kumar, Research article on Antimicrobial effects of Indian medicinal plants against acne-inducing bacteria, Tropical Journal of Pharmaceutical Research, 2007,6(2)

30. Shyam Baboo Prasad, In vitro Anti Acne activity of ethanolic extract of stem of Berberis aristata, $S$

31. Monica Damle, Glycyrrhiza glabra (Liquorice)- a potent medicinal herb, International Journal of Herbal Medicine, 2014;2(2):132-136

32. Aarti Parle, Effect of Yashtimadhu (Glycyrrhiza glabra) churna mukhalepa with honey as an upakarma of Dinacharya (Daily regimen practice) w.s.r. to varnya (complexion), International Journal of Ayurveda and Pharma Research, 2015;5(10), ISSN:2322-0902

33. Baby Joseph, Pharmacocgnostic and Phytochemical Properties of Aloe vera Linn. An Overview, Int. J. of Pharmaceutical Science Review and Research, 2010,4(2); ISSN:0976-044X

34. Rubina Lawrence, Isolation, Purification and Evaluation of antibacterial agents from Aloe vera, Brazilian Journal of Microbiology, 2009; ISSN:1517-8382

35. Dravya Guna Vijnana, Uttarardha, by Yadavji Trikamji, 2/105, Page no:62

36. J.K.L. Tan, A Global Perspective on the epidemiology of acne, British Journal of Dermatology, 2015, 172 (suppl. 1)

37. Aarti Parle, Effect of Yashtimadhu (Glycyrrhiza glabra) churna mukhalepa with honey as an upakarma of Dinacharya (Daily regimen practice) w.s.r. to varnya (complexion), International Journal of Ayurveda and Pharma Research, 2015;5(10), ISSN:2322-0902

38. Monica Damle, Glycyrrhiza glabra (Liquorice)- a potent medicinal herb, International Journal of Herbal Medicine, 2014;2(2):132-136

39. Rubina Lawrence, Isolation, Purification and Evaluation of antibacterial agents from Aloe vera, Brazilian Journal of Microbiology, 2009; ISSN:1517-8382

40. Baby Joseph, Pharmacocgnostic and Phytochemical Properties of Aloe vera Linn. An Overview, Int. J. of Pharmaceutical Science Review and Research, 2010,4(2); ISSN:0976-044X

\section{Source of Support: Nil \\ Conflict of Interest: None Declared}

How to cite this URL: Lekshmy $M$ et al: Efficacy Of Some Indigenous Herbs On Yuvanapidika W.S.R. To Acne Vulgaris: A Review. International Ayurvedic Medical Journal \{online\} 2021 \{cited April, 2021\} Available from: http://www.iamj.in/posts/images/upload/838 842.pdf 